\title{
THE POST-NEOLIBERAL SOUTH AMERICAN DEVELOPMENT
}

EL DESARROLLO POST-NEOLIBERAL DE AMÉRICA DEL SUR

\section{ABSTRACT}

This study addressed the triangular relations between Latin America, Beijing and Washington in the last 15 years using a process tracing technique on the economic and political models of the region. It specifically focused on the South American development during the post-Washington Consensus era, as well as the expanding influence of China over this region. The aim of this paper was to transmit the idea that the failure of neoliberalism in the 90 s together with the expansionism of China have shaped the contemporary political and economic arena among the countries of South America. This work could help to understand the historical process of the construction of develop paradigms on the region and its impact on the society.

Keywords: China, Development, Hegemonic Powers, Latin-America, United States.

\section{RESUMEN}

Este estudio analizó las relaciones triangulares entre América Latina, Pekín y Washington en los últimos 15 años por medio de un rastreo del proceso político y económico de los estados de la región. Se centró especificamente en el desarrollo de América del Sur durante la era post-neoliberal, y la creciente influencia de China sobre esta región. El objetivo de este trabajo fue promulgar la idea de que los medios por los cuales se ha formado la arena política y económica contemporánea de los países latinoamericanos han sido, el fracaso de las doctrinas del Consenso de Washington en los años noventa en conjunto el expansionismo chino. El aporte del presente trabajo va dirigido a la comprensión del proceso histórico de la construcción de paradigmas de desarrollo en la región y su impacto en la sociedad.

Palabras Clave: China, Desarrollo, Poderes Hegemónicos, América Latina, Estados Unidos. 


\section{INTRODUCTION}

The new millennium embodied a breakpoint in Latin American politics. After 20 years of adjustment, which was the subtle term used for referring to the neoliberal guidelines imposed by international financial institutions (Williamson 1990:7), a wave of leftist leaders that promoted anti-neoliberal ideologies gained popularity among the public. The socialist trend started in 1998 with the triumph of Hugo Chavez in Venezuela, followed by the victory of the Workers Party in Brazil led by Ignacio Lula da Silva in 2002. Then, a series of populist left-wing leaders gained power as in the case of Rafael Correa in Ecuador in 2007, Evo Morales in Bolivia in 2006 and the former guerrilla man Jose Mújica in Uruguay in 2010.

Some of this left-winged leader have aligned with the ideas of the ' 21 st Century Socialism', promulgated by Heinz Dieterich in 1996 and then restructured at the Sao Paulo forum by the socialist South American leaders. Rafael Correa (2014) set that it is not considered a model, but a series of principles that allows sovereign governments to generate economic and political models that are suitable for their own domestic reality. The four main principles of this doctrine are:

- Prevalence of human capital over financial capital

- Major use of direct democracy

- Special protection for minority groups

- Self-determination and nationalization (Dieterich 2003:121-129)

Such series of principles have shaped the economic and political models in some states, for instance El Buen Vivir in Ecuador, a model that provides constitutional rights to the Earth and the environment, as well as the Bolivariano model of Venezuela shaped by Hugo Chavez, and the Sumac Kumaña in Bolivia. Such models were aimed to convert Latin America into a region integrated under socialist patterns.

In general terms, during the first decade of this millennium, those projects have demonstrated a positive progress in economic terms. The GDP of the region has grown around $4.5 \%$ each year and the unemployment rates have fallen from $11.2 \%$ in 2002 to $6.4 \%$ in 2011. Furthermore, Latin America has lifted more than 64 million people from poverty and 60 million from the absolute poverty line; and, except for Venezuela, the region has maintained constantly low inflation levels (Cepal 2015). Some authors such as Do Alto (2008), Svampa (2008) and Panizza (2009) have suggested that the autonomy in the Post-Washington Consensus policies have been the key factor that led to South American states to achieve such political and economic stability. However, there are further aspects such as Chinese expansionism that has evidently influenced the progress of the region during the last 15 years.

The South American governments have enjoyed an economic bonanza in the last decade, primarily produced by two factors. First, a boom of the commodities market caused by Chinese demand for raw materials; and second, the increment of capital flows towards the region, from countries like South Korea, Canada, Australia, and expressly from China. Therefore, it is conceivable that the stability of the mentioned leftist governments along with the success of their policies may perhaps be associated in a direct way with the expanding influence from the Asian power over the region. Authors as Manriquez \& Alvarez (2014), Wu \& De Wei (2014) and Philips (2011), have paid special attention to the increasing expansion of Chinese influence over South America.

Nowadays, China is the leading world exporter and the 2nd major economy in the world (Francoise 2013:25-26). In terms of bilateral trading with Latin America, the commerce figures climbed sharply during the first decade of the millennium; the Sino-Latin American trade skyrocketed from US\$10 billion in 2000 to a pre-crisis peak of over US\$143 billion in 2008. China became either the first or second largest trading partner for most Latin American countries. Meanwhile, Latin America has become China's fifth-largest 
trading partner (León-Manriquez \& Hearn 2011:11-12).

As well, for some South American administrations, including the ones in Ecuador, Venezuela and the Argentinean before Macri, the Chinese government has turned into the new alternative for financial assistance, in some way setting aside the influence of the traditional international financial institutions as the International Monetary Found (IMF). Agreeing to Chinese borrowing terms do not include any type of policy reforms or fiscal adjustment.

Instead, the Asian state mostly requires the recognition of the One-China policy and the signing of long-term commercial contracts, headed to supply China a daily fixed quantity of commodities; in most of the cases, oil, minerals and natural gas (Wu \& De Wei 2014:790). In this way, China does not only ensure a long-term supply of commodities, but also gains recognition of its national line of thought. In the same manner, South American governments, benefit from market diversification, as well as financial assistance without any requirements of policy adjustment.

The expanding influence of China over developing regions has brought debates about the geopolitical implications of China's rise. One standpoint perceives China as a threat to the United States' position as the sole superpower. This challenge to US hegemony could be a cause of instability and potential conflict in the future. However, further views have emphasised the peaceful rise of China, and the benefits of its expansionism. One example of it was mentioned before: It is how the commodity boom over the last 15 years, along with the financial aid and specialised investment made by China has brought an economic expansion for developing economies, particularly to South America. In this way, the Chinese economy could be complementary to those of other developing countries that stand to gain from China's growth (Rhys 2010:810-812).

\section{METHODOLOGY}

This scientific paper is the result of a research that aimed to investigate the connexion that exist between the failures of the Neoliberal guidelines in the South American countries during the 90s and the Chinese expansionism over the world. The connexion will be reflected on the change of the development paradigms that has shaped the contemporary political-economy arena of the region. At the end of this work paper, the reader will acquire an understanding about the way in which the upsurge of the Chinese power has influenced the policy-making of the South American states over the last 15 years. The argument will be developed over 3 parts.

The first one will be dedicated to discussing about the on-going power shifts in the international-political arena. This part will include a narrative about the failure of the Washington Consensus guidelines, as well as a clarification about the details of the contemporary power struggle between the main contemporary hegemonic powers, in order to recuperate this data, the study used a documentation of primary and secondary sources. The aim of this section is to set the actual scenery of the interrelations between Beijing, Washington and South America.

The second part aims to define the connection between the Chinese expansion and the rise of leftist governments in South America. This section will include a study about the uprising of the left over the region, particularly after the failure of the Washington Consensus. It also will include an illustration of the macroeconomic indicators of the performance of the region over the last 15 years, with the intention of evaluating whether the domestic policies created in some countries of South America after the Washington Consensus have created real development in the region or if it was merely a fictitious growth. 
Finally, the third section will provide 3 particular case study using a process tracing technique, in which by analysing the neoliberal guidelines that led Argentina, Bolivia and Ecuador to a financial or an economic crisis, along with a study about expansion in economic and diplomatic bilateral relations with China, I aim to offer a narrowed and accurate perspective of the way in which these factors have been an essential foundation for the construction of the current economic and public policies of those countries, as well as the real impacts these policies have had during this period of time.

\section{RESULTS AND DISCUSSION: The Decalogue for Development}

During the 60s and the 70s, Latin American states acquired substantial sums of foreign debt, particularly with the IMF for adjusting the disproportion on its balance of payments. Such imbalances were mainly caused by the inefficiency of import substitution policies that those states maintained after World War II.

An example of such practices was using foreign loans to protect the state enterprises, compensating its inefficacy and making them able to compete at domestic level. In this way, the South American states were using the financial loans provided by the IMF not only to correct macroeconomic imbalances, but also to finance the public industry deficit. By 1980, most Latin America economies became immersed in economic stagflation, mainly triggered by the collapse of the raw materials markets and the US Dollar appreciation (Rangel \& Soto Reyes 2012:42).

In 1982 the Mexican state, which was unable to borrow, ran out of financial reserves and this situation ultimately led to default on its foreign debt. The Mexican default triggered a series of complications for all Latin American states. The US authorities alleged that to avoid a contagious inflation, it was necessary to restrict the quantity of money circulating in the economy. Thus, the North-American state increased their interest rates producing a rise in the price of their currency. The Latin American states, which were indebted in US Dollars, attained a foreign debt capable to reach record levels. Consequently, much of states in the region fell into a situation that made them unable repay their foreign debt.

To avoid a massive default, the international institutional creditors came into the rescue. However, they also viewed a perfect opportunity to extend the neoliberal system to South America (Rangel \& Soto Reyes 2012:40-45). After the failure of the Cepalist model of import substitution, the Latin

Figure 1: Chart shown the evolution of the foreign debt in the major economies of South

America and Mexico in the period between 1970 and 1990.

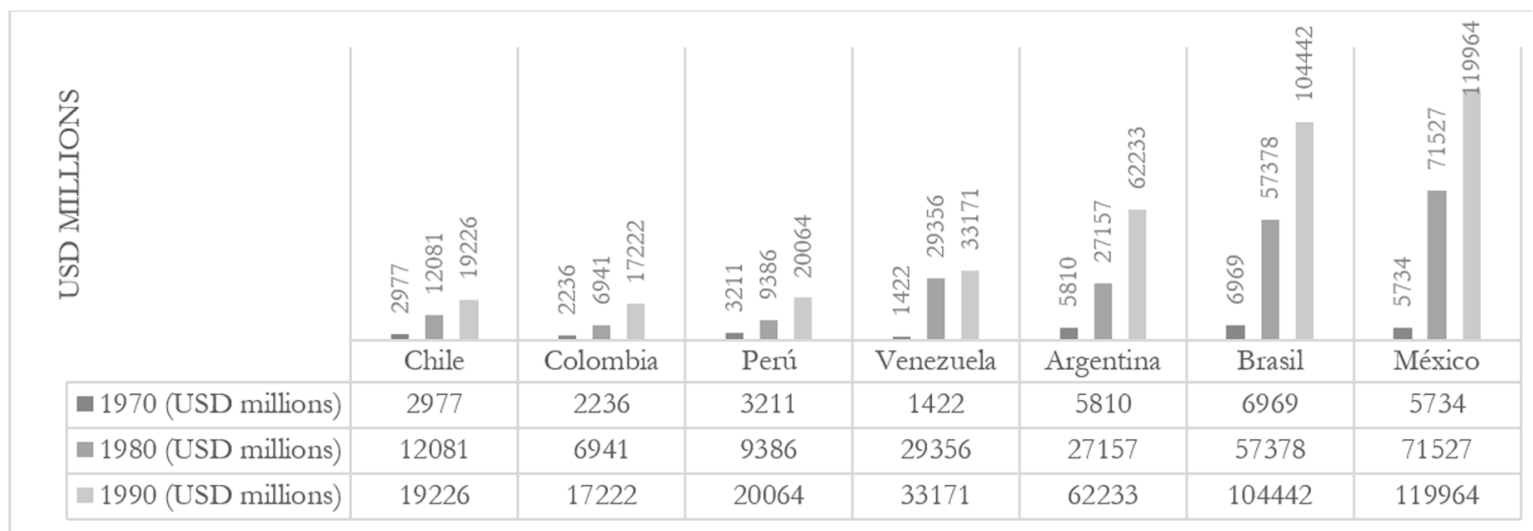

Source: Data retrieved from Toussaint, (2003). 
American states were required an open, stable and liberalized economic model.

At least this was the prescription that neoliberal economists of the time suggested, including Williamson (1990) and Richard (1990). This is how the neoliberal guidelines were crystallized with the formulation of the Washington Consensus. A Decalogue of policy reforms which fundamentally proposed that economic reforms should be based on the logic of the markets, besides from being characterized by openness and macroeconomic principles. The Washington Consensus could, therefore, be summarized by ten main guidelines:

- Fiscal Discipline

- Redirection of public expenditure towards education, healthcare and infrastructure

- Tax reforms to extend the tax base

- Interest rate liberalization

- A competitive exchange rates

- Trade liberalization

- Liberalization of foreign investment inflows

- Privatization

- Deregulation to commerce

- Property Rights (Williamson 1990)

The effects of the Washington Consensus over Latin America raised, and still raises, several arguments concerned with debates about the triumph or failure of liberalism and the way in which globalization is perceived. However, it is undeniable that the liberal guidelines were unsatisfactory for Latin America since they did not accomplish their main objective.

As a matter of fact, after a decade of its implementation, states such as Argentina, Bolivia, Brazil, Ecuador, Paraguay, Venezuela and Uruguay were hit by a series of economic, financial and political issues that could most certainly be linked to the unsatisfactory reaction of the public towards the neoliberal policies implemented during the 90 s. In addition, the implementation and the maintenance of the neoliberal policies caused the South American countries to acquire an even larger amount of foreign debt.

Such a situation produced a vicious cycle, in which the states needed money to maintain the neoliberal policies, but then again, the International Financial Institutions only provided them conditionally loans, upon the implementation of further neoliberal policies. Such a situation made it impossible for the South American states to redirect the money of their loans to matters that would enhance their development like education, infrastructure and technology. Instead it was used to pay the cost of policy implementations, and

Figure 2: Shown the position of China and United States in trade ranking position with Latin

American states during the years 2000-2010.

\begin{tabular}{|c|c|c|c|c|c|c|c|c|}
\hline & \multicolumn{4}{|c|}{ China } & \multicolumn{4}{|c|}{ United States } \\
\hline & \multicolumn{2}{|c|}{ Exports } & \multicolumn{2}{|c|}{ Imports } & \multicolumn{2}{|c|}{ Exports } & \multicolumn{2}{|c|}{ Imports } \\
\hline & 2000 & 2010 & 2000 & 2010 & 2000 & 2010 & 2000 & 2010 \\
\hline Argentina & $6^{\text {th }}$ & $4^{\text {th }}$ & $4^{\text {th }}$ & $3^{\text {rd }}$ & $2^{\text {nd }}$ & $3^{\text {rd }}$ & $2^{\text {nd }}$ & $2^{\text {nd }}$ \\
\hline Brazil & $12^{\text {th }}$ & $1^{\text {st }}$ & $11^{\text {th }}$ & $2^{\text {nd }}$ & 1 & $2^{\text {nd }}$ & $1^{\text {st }}$ & $1^{\text {st }}$ \\
\hline Paraguay & $15^{\text {th }}$ & $15^{\text {th }}$ & $3^{\text {rd }}$ & $1^{\text {st }}$ & 6 & $11^{\text {th }}$ & $4^{\text {th }}$ & $6^{\text {th }}$ \\
\hline Uruguay & $4^{\text {th }}$ & $4^{\text {th }}$ & $7^{\text {th }}$ & $3^{\text {rd }}$ & 3 & $7^{\text {th }}$ & $3^{\text {rd }}$ & $4^{\text {th }}$ \\
\hline Chile & $5^{\text {th }}$ & $1^{\text {st }}$ & $4^{\text {th }}$ & $2^{\text {nd }}$ & $1^{\text {st }}$ & $2^{\text {nd }}$ & $1^{\text {st }}$ & $1^{\text {st }}$ \\
\hline Colombia & $36^{\text {th }}$ & $6^{\text {th }}$ & $9^{\text {th }}$ & $2^{\text {nd }}$ & $1^{\text {st }}$ & $1^{\text {st }}$ & $1^{\text {st }}$ & $1^{\text {st }}$ \\
\hline Venezuela & $35^{\text {th }}$ & $2^{\text {nd }}$ & $18^{\text {th }}$ & $2^{\text {nd }}$ & $1^{\text {st }}$ & $1^{\text {st }}$ & $1^{\text {st }}$ & $3^{\text {rd }}$ \\
\hline Costa Rica & $30^{\text {th }}$ & $2^{\text {nd }}$ & $15^{\text {th }}$ & $3^{\text {rd }}$ & $1^{\text {st }}$ & $1^{\text {st }}$ & $1^{\text {st }}$ & $1^{\text {st }}$ \\
\hline Guatemala & $43^{\text {rd }}$ & $25^{\text {th }}$ & $19^{\text {th }}$ & $3^{\text {rd }}$ & $1^{\text {st }}$ & $1^{\text {st }}$ & $1^{\text {st }}$ & $1^{\text {st }}$ \\
\hline Mexico & $19^{\text {th }}$ & $7^{\text {th }}$ & $7^{\text {th }}$ & $2^{\text {nd }}$ & $1^{\text {st }}$ & $1^{\text {st }}$ & $1^{\text {st }}$ & $1^{\text {st }}$ \\
\hline
\end{tabular}

Source: Data retrieved from Cepal Stats (2015). 
the repayment of their debts with higher interest rates. Consequently, these states were not able to industrialize their production and were condemned to be indebted raw material exporters (Rangel \& Soto Reyes 2012:4657).

\section{The Chinese expansion and the US hege- monic decline}

While Latin America entered a decade of economic stagnation in the $80 \mathrm{~s}$, China on the other hand was starting a period of rapid economic growth. Since the 80s, the Chinese economy not only has grown at almost 10 per cent per annum, which resulted in a sevenfold increase in the income per capita. But it has also become the second-largest economy in the world. Furthermore, its successful reintegration to the global economy had situated the Asian power as the world's largest exporter ahead of Germany and Japan. In addition, Chinese companies such as Sinopec and China National Petroleum have become key players in the commodities market, particularly in the extraction and energy industries. Since 2000, the Asian power has been expanding its influence in the world beyond commerce. China started having a major impact on the political, financial and diplomatic affairs.

Manriquez \& Alvarez (2014), demostrated how Latin America is still a highly economic-dependent region, and also they outlined the ideological, political and mostly economic fissures of the relations between United States and Latin America. They went on to explain how China is taking advantage of this situation in order to gain more influence over the Latin Amercian region. Even though the general perspective of the US-Latin American relations shows a solid compromise, the reality is revealed when the studies are geographically separated. As it could be seen in table 2, the total trade between the two parties rose from US\$ 339 billion in 2000, to US\$ 586 billion in 2012. In addition, Latin America has gained relevance in US foreign trade figures. In 1990, the region accounted for $13.3 \%$ of US ex- ports and $12.9 \%$ of US imports. By 2009, the respective shares increased to $22.1 \%$ and $18.1 \%$ respectively (Cepal 2015). However, $58 \%$ of US trade with Latin America took place with Mexico, and the commercial flow of the nineteen other states accounted for just US\$ 340 billion. Furthermore, while the United States is still the major commercial partner of almost all the countries in Central America and in the Caribbean, China has displaced the United States as the major commercial partner in many South American states (Manriquez \& Alvarez 2014:8-14).

There are several factors that are contributing to the capacity of China to overstep the United States' economic and political influence in the region. For Manriquez \& Alvarez (2014:11-12) the list includes first, the geographical conditions, in which the United States is still able to influence states with geographical contiguity, but is inefficient to maintain its control over all the states in the region. Second, the US neglect for Latin America due to its focus on the Middle East. And third, a lack of trust in the orthodox neoliberal guidelines.

On the other hand, China has emerged in Latin America as the new financial alternative. China has disbursed since 2010, more than US\$110 billion in high-level investment to Latin America and nowadays has become the 3rd highest investor in this region. Furthermore, China has become a donor-member for the Inter-American Development Bank (IDB), providing China a seat on the Board of Governors, allowing China the capacity to influence decision-making in terms of financial policies and investment of the 26 Latin American countries part of the IDB (Wu \& De Wei 2014).

The financial power of China is becoming its most efficient weapon to expand its influence. Nowadays, China has accumulated US\$3.4 trillion of official foreign exchange reserves. Furthermore, it is the second biggest creditor of the US foreign debt (US $\$ 1164$ billons [7.5\% of the total United States foreign debt]). Although the United States still maintains privileges due the position of the US dollar as the key currency of 
the world, the massive accumulation of Chinese financial assets has situated the United States in a very sensitive position, as the Chinese expansion of financial influence over the United States is affecting its hegemonic political capabilities. Thus, the United States is watching carefully how China continues to expand its influence over the South American region, and considering how best to act to not affect its own financial stability.

The former Australian Prime Minister, Kevin Rudd (2015), now president of the Asia Society Policy Institute, declared that:

If China does become the world's largest economy, it will be the first time in 200 years that in the world we will have as the largest economy a non-English speaking country, a non-Western country, and a non-liberal democratic country...It will affect so many things at so many levels. It will go to the absolute core. It's happening quietly. It is happening persistently. It is happening in some senses under the radar'. (Rudd 2015:1)

Such description perfectly captures how China has expanded its influence over developing regions, particularly in North Africa and Latin America. Being a great power has never been solely about the possession of large amounts of crude material power. It has been closely related to notions of legitimacy and authority, in this way, the Chinese power has been combined with a long-term sense of where it would like to be and that, as a state, it must date maintained a significant degree of strength and coherence (Hurrell 2006). Since 2001, the presence of China in South America has intensified, and this it is not a coincidence.

The affiliation of China to the World Trade Organization (WTO) changed commercial rules all over the globe. The leftist governments saw an opportunity to expand their markets to Southeast Asian states and particularly to China, which had already started to increase its commerce over the region during the late 90s. The commercial guidelines of all the South American states have started to include openness to Chinese markets as key goals in their foreign and commercial policies (Oliva 2010:113).

Attempting to generate a different scheme of cooperation comprising the non-Western Southern regions of the globe, China has chosen a softer pattern of influence, which has given the impression to be solely concerned with commercial matters at first glance, but later pursuing political and diplomatic acknowledgment. For instance, China has changed its policy and now can expand its commercial flow and direct its investment towards developing countries that still maintains good relations with Taiwan, such as Honduras, Guatemala and Paraguay. This has been done deliberately with the aim of opening further diplomatic channels later down the line, such as happened in 2004 and 2007, with the Dominican Republic and Costa Rica respectively, both Caribbean states which have maintained a historical scheme of cooperation with Taiwan but switched rapidly their diplomatic recognition of the People's Republic of China when they perceived that doing so would be beneficial (Manriquez \& Álvarez 2014:22) (Wu \& De Wei 2014:795-797).

China is also pursuing a recognition as a market economy state, regardless of its mercantilist practices, which include an artificial depreciated currency exchange rate, dumping, copyright infringements, various cases of child labour and extreme working conditions. In South America, states as Argentina, Peru, Venezuela Brazil and Chile, without regard of the counter effects that such conditions have on their own commercial sectors, have granted China the condition of a market economy state, since Chinese officials have imposed this condition to continue a commercial and financial scheme of cooperation (Urdinez 2014).

The Sino diplomacy and its influence for the upsurge of the leftist policies in the South

Wu \& De Wei (2014:789-799), have recognized two main areas of Chinese foreign policy influence over Latin American states. 
The first is concerned with finances and the economy. It includes oil negotiations, commercial reliance, borrowing and investment. The second area is about diplomatic recognition and political expansionism, including the global recognition of the 'One China' Policy.

One of the bases of the success of the Chinese expansion in South America had been related to the platforms that China used since 2000 for engaging with these nations in economic affairs, leaving the pursuit of diplomatic recognition as a secondary priority. By doing so, China has been welcomed by the South American states as an option to diversify its markets and for obtaining financial aid and investments. China has focused on creating solid relations based on economic and financial matters first and, after securing these, branching out into the diplomatic and ideological arena. It is evident that China has learned the lesson of the failure of the neoliberal scheme managed during the 80 s and the 90s. (Wu \& De Wei 2014:800)

The leftist projects in Latin America demonstrated decent outcomes, which could be validated by both the popular acceptance of the leftist leaders during their administrations as well as the good results given by macroeconomic indicators, which shown a consistent expansion on the GDP growth rates per year and a decrease in inflation and unemployment rates; in comparison to the numbers during the Washington Consensus reforms in the 90s. However, since 2014, the popularity of the leaders has started to decline, because of two important factors. First, criticism about the increasing levels of accumulation in both public and foreign debt, particularly with China. And second, the reckless allocation of public funds, especially in the Andean region administrations, including Bolivia, Ecuador, Argentina but, most expressly, Venezuela.

Saul Quincy (2011) determined that these are common problems with socialist models, which denote the unsustainability of such projects for two reasons. Firstly, because leftist leaders have only focused on winning socialist goals, preventing any alternative for the model that they have proposed and therefore showing the populist and self-interested characteristics of such models. And secondly, due to the lack of empathy of the professionals and middle classes towards the social policies, probably because they have been educated under neoliberal bases. In Venezuela for instance, the professional class is so ideologically capitalist that even doctors must be imported from Cuba to work in the public sector as, so few Venezuelan doctors are willing to treat the poor if their personal income is affected. (Quincy 2011)

\section{The Argentinean Case}

In Argentina, six of the ten neoliberal policies were applied for the economic restructuring of the state including a fixed nominal exchange rate, trade liberalization, an intensive privatization scheme, and deregulation of the labour conditions, allowing outsourcing and non-contractual ways of employment. Silva (2015), studied the reformation into two sub-periods.

The first period of boom, started in 1991 and extended up until the third quarter of 1998 and the second one of crisis, which begins in the fourth quarter of 1998 and lasts up to the end of 2001. It is true that during the first period the neoliberal policies had an acceptable performance, not only by facilitating the expansion of the Argentinean markets, but also by pressuring companies to become more productive.

However, the flipside of this process was the accumulation of financial and fiscal imbalances caused by the cost of implementing and maintaining these neoliberal policies, especially the cost of maintaining the parity of the Argentina Peso to the US Dollar. In addition, there was a deterioration in state power due to the austerity measures imposed, which was clearly expressed in the breakup of the alliances in parliament, and a general loss of legitimacy among their electoral base, producing apart from the economic unproductivity, a profound political instability.

The Argentinean crisis best known as the Corralito was triggered in 2001 when the IMF 
refused to release US\$1.3 billion, alleging the failure of the Argentinean government to reach a previously agreed-upon budget deficit target, while it also demanded further budget cuts. This episode not only caused a national demonization of the neoliberal institutions but also the spreading of a sense of discomfort to the whole population, especially to the most affected working classes. The situation led to a prolonged crisis, which ended in financial bankruptcy and a severe decline on real economy. Argentina ended in a situation where the bank accounts of the people were frozen for weeks, and $50 \%$ of the population officially became poor while another $25 \%$ was below the absolute line of poverty (Silva 2015).

The Argentinian financial is one example of a vast range of events that demonstrated not only the unpopularity of the neoliberal policy among Latin Americans, but also the means in which the reckless implementation of these policies was never able to adjust to the South American reality, resulting in a fiasco that cost all the countries of the region various decades of unproductivity and large sums of financial obligations.

Although there is still a divergence of opinions about the outcomes of the Washington Consensus in South America, a general perception among the authors, regardless of whether they are supporters or opponents of neoliberal dogmas and including the perspectives of Cavallo (2004), Silva (2015) and Rangel \& Soto Reyes (2012), is that the Washington Consensus left a sense of economic openness in Latin America and helped to rationalize the concept of globalization for Latin Americans. Nevertheless, it also left an unpopular notion about neoliberal institutions and the scheme in which they were regulated.

The new-born Sino-Argentinean relations during the Kirchner administration were a good example to demonstrate the influence that Chinese diplomacy has over the economic and political decisions taken during this period. In 2003, after several interim presidents, the left-wing leader, Nestor Kirchner became Argentinean president. The Kirch- ner administration pursued an autonomous economic policy that was contrary to the guidelines imposed by the IMF in the $90 \mathrm{~s}$.

The main objective of the Argentinean government became the repayment of the debt, with the intention to disassociate the country from neoliberal prescriptions imposed by the multilaterals. Since its first day in the administration, Kirchner implemented a series of social programs to reconsolidate the Argentinean people's trust in the government and such measures boosted his popularity among the public and provided political stability to Argentina (Panizza 2009:245). In 2006, Argentina achieved its national goal by paying its debt with a single payment of US\$ 9.2 billion (Navarro 2015). It could be said that somehow, the autonomous policies recovered the Argentinean economy and made the state able to repay its debt obligations. However, there is an essential factor which facilitated the Argentinean recovery, and such factor indeed is China.

Since 2003 the strategic foreign policy goals of Argentina started to include guidelines which encouraged openness and enhancement of diplomatic and commercial relations towards the Asiatic power. In fact, China was considered one of the seven great pivotal points of Argentinean commercial policy which aimed to create permanent, balanced and mutual bilateral ties. In 2004, Kirchner visited Beijing and Shanghai accompanied by his ministers and his wife, Cristina Fernandez, who in 2007 would be elected as President of Argentina. This was the first of many future encounters between Argentinean and Chinese leaders. Because of such visits, a series of bilateral agreements were signed, mostly to promote mutual investment and to encourage the creation of Sino-Argentine companies.

For China, the recognition as a market economy by the government of Argentina was a key issue. However, the Argentinean state was applying 79 anti-dumping measures per year to Chinese products to protect its industry and workers. Nonetheless, China was offering a considerable increase in investment towards Argentina's productive 
sectors and infrastructure, besides it provided Argentina the status of tourist destination and, most important, accepted to provide the financial aid that Argentina needed to fulfil its national prime objective, which was to pay back the debt. What's more, Hu Jintao had already gained the recognition from Brazilian's president, Luiz Ignacio Lula da Silva, which would have conditioned the bargaining power of Argentinean officials who knew that granting China the condition of 'market economy' could produce dangerous effects on their national industry. Yet, before Jintao left South America, the negotiations concluded with the signing of a 'memorandum of mutual understanding' which recognized China as a market economy state (Urdinez 2014:70-73). This exposed the vulnerable sectors of the Argentinean economy and demonstrated the capabilities of the Chinese officials who, by including financial and commercial matters into the bargain, can influence a country's diplomacy and ideology.

In addition, since 2005, Chinese injections of capital started to be introduced into Argentina's economy through direct investment and lending. The same year, China purchased Argentinean debt bonds, which were mainly issued with the purpose of meeting its financial obligations with the IMF. So, because of this, further Chinese investment was used for improving the public infrastructure such as highways and railways. In return, Argentina agreed to take a common stance against US and European agriculture subsidies in the WTO (Urdinez 2014).

Since 2006, there has been a series of bilateral agreements signed by both parties with the aim of boosting cooperation in areas that include natural gas, tobacco and pharmaceutical commercialization, as well as tourism, educational services, and biotechnology transfers, and the consolidation of the China-MERCOSUR agreement. Furthermore, in 2009, a fund of US\$ 11 billion in Pesos and Renminbi was created between the Argentinean Central Bank and the People's Bank of China to set commercial transactions in both national currencies. Hence, both countries have cooperated in taking small steps to set aside dependency on the US dollar for international transactions (Oliva 2010:104-105). By the analyses of the present Sino-Argentinean relations, it is possible to observe that the interrelations of both countries go beyond the economic and commercial matters. Nowadays, it is clear to observe a demarcated scheme of cooperation between these nations that include diplomatic, political and ideological bonds. China was a crucial player in the Argentinean recovery and nowadays plays a fundamental role as commercial partner and investor for the maintenance of its policies. On the other hand, Argentina has become largely dependent on China, which has demonstrated the power to influence Argentinean executive decisions.

\section{Bolivia, Morales and China}

After 20 years of neoliberal guidelines, the Bolivian state was immersed into a profound economic and social crisis. The Washington Consensus policies brought to this country, an increment in poverty rates while wealth was accumulated by a few sectors and taken outside the country. Furthermore, the gap between rich and poor widened, the informal economy numbers skyrocketed, and the high levels of unemployment caused people to work for less than US \$ 1 per day (Rowan 2003:2-3).

Such precarious conditions resulted into a natural response in which Bolivian taxpayers redirected their frustration to oppose any neoliberal policy. For Do Alto (2008) and Panizza (2009), the failure of the Washington Consensus guidelines triggered the popularity of the left anti-elitist leader, Evo Morales, which appeared with a demagogically-social discourse that not only attacked aggressively the neoliberalist line of thought, but also induced a feeling of nationalism within the Bolivian collective mind. Since Bolivian policies took a shift against neoliberalism (Rowan 2003:2).

A brief valuation of social and economic indicators of Morales' administration shown that the GDP has been constantly growing around $4.1 \%$ and $6.1 \%$ each year. In addi- 
tion, the minimum wage escalated from US\$ 57 in 2003 to US\$ 238 in 2015, furthermore, the infant mortality rate was reduced by $60 \%$ and most importantly, 3 million people have been lifted out of poverty and 1.7 million from extreme poverty (Cepal 2015). Although the Bolivian economy is still fragile and dependant, the left policies of the multicultural state have demonstrated remarkably better outcomes than the results produced by the policies applied during the neoliberal period; however, again China, was an important player that aimed for such development. There are two important factors in the Evo-Bolivian model. The first one stands for the nationalisation of public goods, such as water and electricity, as well as the ones concerned with extraction of hydrocarbons and mining, which are constitutional recognized as strategic resources. Do Alto (2008:177183) studied the effects of the nationalization of companies in Bolivia, so he remarked that in addition to the new Constitution, there are two key legal reforms that helped the Bolivian government to succeed in the nationalization process without using the figure of expropriation.

The first was the supreme decree N. 29701 and the second the Hydrocarbons' law. The first established that $82 \%$ of the profit of big companies in the extractive industries should go to the state and $50 \%$ of the profit for the minor ones. The second one dictates that all the hydrocarbon resources belong to the state. As a result, the Bolivian govern- ment has been able to benefit directly from the boom in the commodities market of the last decades. The Bolivian government has already gained control of $19 \%$ of the Bolivian GDP, and the national objectives expect that they can get control of $30 \%$ of its GDP. The second factor is related to an increase of exports, mainly attributed to the diversification of its markets, predominantly towards China.

In the last decades, the Chinese industrial production has diversified from its traditional industries such as toys and textiles production to further segments such as machinery and chemical production. The rapid development of China's productivity base has increased its demand of raw materials. Since 2001, China has become the greatest importer of minerals and metallic commodities such as tin, zinc, steel, lead and copper. Which produced that the global raw material supply was insufficient to go together with the world's growing demand for such products. Consequently, the prices started to rise rapidly and created a boom in the commodities market (Poveda 2010:153-154). The boom in the new Sino industries caused Bolivia to flourish during the last decades. The Bolivian economy is limited to the supply of natural resources, and as an exporter of only a few commodities, it is highly sensitive to any matters that occur in the global markets. Consequently, the multicultural state benefited greatly from the commodity boom caused by the Chinese demand.

Figure 3: show the partners share in Bolivian commercial flows from 1996 to 2006.

\begin{tabular}{|l|c|c|c|c|}
\hline \multicolumn{1}{|c|}{ Region } & \multicolumn{2}{|c|}{ Imports } & \multicolumn{2}{c|}{ Exports } \\
\hline & 1996 & 2006 & 1996 & 2006 \\
\hline CAN & $20.12 \%$ & $9.78 \%$ & $8.75 \%$ & $9.37 \%$ \\
\hline Asia and China & $13.65 \%$ & $15.39 \%$ & $0.32 \%$ & $9.87 \%$ \\
\hline EU & $14.56 \%$ & $8.63 \%$ & $24.50 \%$ & $5.82 \%$ \\
\hline US & $28.09 \%$ & $12.15 \%$ & $25.01 \%$ & $9.74 \%$ \\
\hline MERCOSUR & $20.04 \%$ & $39.57 \%$ & $14.59 \%$ & $52.14 \%$ \\
\hline Total (USS Millions) & 1634.0 & 2804.0 & 1307.0 & 4245.0 \\
\hline
\end{tabular}

Source: Data retrieved from INE (2007). 
Compared to the 90s, in the XXI century, Bolivian exports have increased from US\$ 1307 million in 1996, to US\$ 4245 million in 2006 (INE 2007). Such increment is the result of a market diversification, as can be seen in the Figure 3. Export growth to Asia and China was especially remarkable with an increase from $0.32 \%$ of Bolivian exports share in 1996 to $9.87 \%$ in 2006. Thus, Asia has become Bolivia's second most important trade partner in the region. On the other hand, it is possible to observe that the trade share of the US and the EU has plummeted. This situation could be a result of Evo Morales's resolution to refuse to sign a free trade agreement with the US as well as the nationalization of European and North-American companies.

Chinese investment has also played a key role in Bolivian economic expansion. There are two recent projects of cooperation between China and Bolivia that prove this. The first is an agreement for a joint venture between the Chinese company Shengli and the Bolivian Ministry of Hydrocarbons, in which Shengli will invest almost $\$ 2$ billion in the assessment, extraction and processing of petroleum and natural gas in the north of the $\mathrm{La} \mathrm{Paz}$ region.

And the second is a cooperation project in which both governments will invest in the elaboration of a geological map of Bolivia. For these projects China will invest $\$ 60 \mathrm{mi}-$ 1lion in the elaboration of $70 \%$ of Bolivia's geological map. Consequently, Bolivia will be able to vastly improve their hydrocarbon and mining industries, while China would then have a preference in the extraction business (Poveda 2010:160-165).

\section{Populism in the bonanza}

China played an important part in the maintenance of the populist practices of some administrations. The direct investment, financial aid, and the increasing commercial flow have brought extraordinary revenues for the Latin American governments. Such incomes have been redirected in some states to populist practices to boost the popularity of the leaders.

For example, in 2007, Costa Rica followed the road of the Dominican Republic that in 2004 cut relations with Taiwan, due to an encouraging offer from The People's Republic of China that could boost their popularity among the public. China offered that, in exchange of the recognition of the 'One-China policy' Costa Rica and the Dominican Republic will receive US\$ 100 million and US\$ 122 million respectively for the construction of national stadiums. Both countries found that this offer was more beneficial than Taiwan's offer, that included US\$70 million in aid for Costa Rica and 6.8 US\$ million in assistance for the Dominican Republic (Wu \& De Wei 2014:789).

Figure 4: Graph that illustrate the price variation of Oil and Natural Gas (1999-2015)

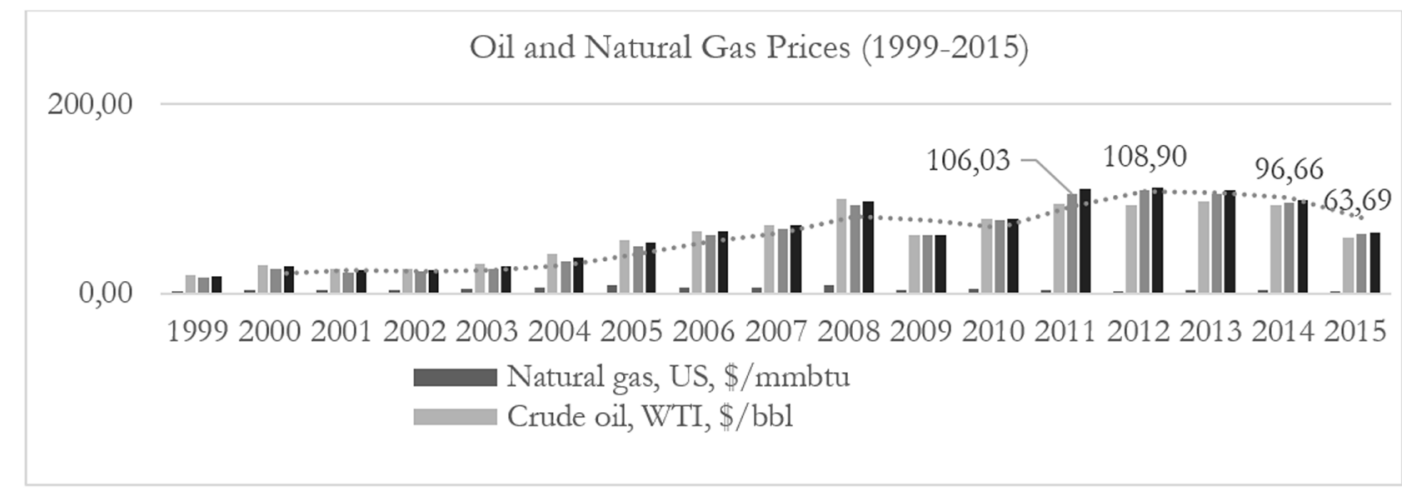

Source: Data retrieved from World Bank, Global Economic Monitor (GEM) Commodities, (2014). 
A further case of social polices includes countries as Ecuador, Bolivia and Venezuela which have been able to expand the public sector, and to reduce unemployment rates by using Chinese foreign investment to create unproductive public entities to provide jobs. For example, when Hugo Chavez got elected, Venezuela had 16 ministries. By 2013, the number of ministries doubled to 32 and employed $19.6 \%$ of the Venezuelan labour force; while in Colombia, which maintained a pro-market system, there were 16 ministries which employed $3.5 \%$ of the Colombian labour force (Torres 2015).

Venezuela has received US\$ 42.5 billion in loans from the Chinese Development Bank for improving public infrastructure. Nonetheless, in lending terms, the infrastructure includes the construction, renovation and expansion of public buildings which were used to house new public entities with the aim of producing artificial jobs (Wu \& De Wei 2014:92).

The expansion of the Venezuelan public sector which meant an extensive increase in the public spending has only been possible as it was financed by the extraordinary revenues that Venezuela has received during the last decades as product of the high prices of oil during this period. Venezuela's oil revenues, according to the Opec (2015), accounts for about $95 \%$ of export earnings and the oil and gas sector represents around $25 \%$ of the Venezuelan GDP.

In 2014, when the commodity boom ended, and the prices of fossil fuels dropped, Venezuela's president, Nicolas Maduro, implemented an emergency readjustment program to cut public spending, reducing its number of ministries to 28 . The Venezuelan oil barre1s went from a price of around US\$ 100 per barrel, to US\$ 55 per barrel in 2015, causing an economic recession and a deficit in the balance of payments and resulting in uncontrollable inflation of $52.7 \%$, and an expansion in the numbers of Venezuelans who live in poverty and extreme poverty conditions (32.5\% and $9.8 \%$ correspondingly). Consequently, Nicolas Maduro travelled last April to China to renegotiate its existing debt by adding a US\$ 5 billion loan to save its economy (Ellsworth 2015).

\section{The Case of Ecuador: from the Neoliberal Financial Crisis to Revolution of Correa}

Sobered by the debt crisis from the $80 \mathrm{~s}$, Ecuador started a series of restructuring programs during the $90 \mathrm{~s}$, in accordance with international financial institutions to implement the neoliberal guidelines of the Washington Consensus. Nazmi (2001:727) has claimed that the reckless implementation of such reforms caused dangerous macroeconomic imbalances to the Ecuadorian economy, leading to a profound crisis which resulted in the loss of its national currency.

There are 3 fundamental policies which led the Ecuadorian state to its economic collapse. First, a reckless scheme of privatization that did not match the national reality of the state. Second, the artificial imposition of a pegged exchange rate that produced a lack of liquidity and speculation resulting from dangerous liberal prescriptions. And third, the lack of autonomy of the state administration to produce regulatory policies to prohibit irresponsible practices from a weakened and corrupt private banking sector.

In 1992 the American-born Sixto Duran Ballen was elected as the 37 th president of Ecuador. Duran Ballen, who was considered a pro-neoliberal republican, implemented an innovation model in Ecuador. Such a model included provisions to reduce the Ecuadorian public deficit through austerity measures and a privatization scheme of the national companies. In 1993, the Ecuadorian congress approved the plan through two legislations. First, the Budgetary Law of the Public Sector, and second, the 'Privatization and Modernization Law'.

Both regulations were aimed to downsize the government spending, privatize public companies and enhance international competition. The first regulation delivered rapid results. The state reduced its public-sector expenditure from $31.4 \%$ of total GDP in 1987 to $24 \%$ in 1994 , producing a surplus of $0.6 \%$ of the GDP in the Ecuadorian balance of payments at the end of that year. Such 
an outstanding short-term result generated a compensation coming from the IMF, which reduced the interest rates for the Ecuadorean loans by up to 5\% (Nazmi 2001:728-729).

In 1995, because of the budget cuts that caused a reduction of labour places in the public sector, the unemployment rates started to increase rapidly. Furthermore, the privatization scheme was still lacking results. The Ecuadorian state had achieved privatization of only 11 enterprises while Argentina and Bolivia, which were following the same policy guidelines, had accomplished privatisation of 131 and 57 companies respectively (Nazmi 2001:730). The Ecuadorian economy, therefore, was not able to expand as was expected. Furthermore, the private sector lacked the efficiency to produce enough employment to compensate for jobs lost in the public sector during the adjustment period.

To attract foreign investment, the Ecuadorian government followed neoliberal prescriptions that were applied by the rest of the administrations in the region which dictated the liberalization of capital movements to provide further financial security to foreign investors. Owing to this, the Ecuadorian administration decided to reform its financial legislation. The reforms included the possibility of the creation of US\$ Dollar accounts in local banks, the establishment of offshore accounts, and a pegged exchange rate for the national currency.

For several scholars including Nazmi (2001), this was the beginning of what would become the financial crisis of 1999. After a while, the results delivered by the new legislation diverged from what the government was expecting. In the first place the freedom of capital movements along with the constitutional reforms repealing the state ownership of strategic resources as oil and energy, instead of bringing real and long-term investors, attracted short-term capital investments, better known as swallow capitals.

The major part of the oil revenues was transferred outside of the state, due the absence of capital movement regulations (Berriosa Marakb \& Morgensternc 2011:675-681). The neoliberal guidelines were clearly providing a list of benefits to the private entities, while the rates of poverty and unemployment were critical in the state, demonstrating that the foreign investment prescriptions mean neither economic growth nor social development.

The collateral effects of the new financial legislation were inevitable. Since it permitted the banking sector to generate offshore and US\$ Dollar accounts, the Ecuadorian financial institutions of that time restructured their balance sheets to reposition their portfolios away from Sucres and into US\$ Dollars. In this process, the banks, which were poorly regulated, expanded their balance sheets recklessly. Imprudent practices included a relaxed credit risk analysis and resulted in a credit rise of $48 \%$ per year during 1994 to 1996.

Such unhedged exposure to dollar liabilities conditioned the Ecuadorian monetary policy, which prevented the Central Bank from devaluating its currency. Such a situation not only undermined the Ecuadorian exporting sectors, but also created a moral hazard for the banks, which continued with their careless operations, which triggered a rapid expansion in the Ecuadorian internal debt figures, as well as a massive increase in its percentage of debt in foreign currencies which by 1998 were about US\$ 987.03 million, from which $91 \%$ was in foreign currencies (Banco Central del Ecuador 2003). Nazmi (2001:733-734) argued that such artificially pegged exchange rate turned all the previous economic difficulties into a full-fledged financial crisis which was made worse by external factors such as a belic conflict with Peru as well as a series of governamental corruption scandals. These caused the failure of the programs that aimed to stabilize the Sucre exchange rate.

As a consequence, the Central Bank was forced to increase the real interest rates from $1.9 \%$ in 1992 to $36.2 \%$ in 1999 to encourage investors to keep their holdings in Sucres. Because of such desperate policies in conjunction with public speculation, investors started to send their money overseas causing 
a lack of liquidity in the financial sector and resulting in the insolvency of seven banks including Filanbanco.

The government monetized their bank losses causing the collapse of the exchange rate anchor. In 1999, the Sucre depreciated around $200 \%$ and inflation was about $90 \%$. Facing social disintegration and economic catastrophe, the government took the decision to freeze all bank accounts for one year and in 2000 announced the intention to dollarize the economy (Nazmi 2001:733-734).

During a ten-year period (1996-2006), Ecuadorians observed seven different leaders occupying the position of president. However, none of the leaders can provide any type of improvement to the Ecuadorian economy or to the standards of living of their citizens. Nonetheless, in 2007, Ecuadorians elected Rafael Correa as their head of state. Correa was a populist university lecturer, with an academic background in economics who did not have links to the traditional political parties. This fact caused his popularity to spread rapidly among the electorate, which was tired of the traditional representatives (Jaramillo-Jassir 2012:151-152). In 2007, once elected, the new administration started its revolutionary process which substituted the neoliberal regime policies established in Ecuador since the 80 s with policies following a model of endogenous growth primarily favouring the working class.

To legitimate their actions in the political and in the legal field, a referendum, mainly intended to produce a new constitution that included all these reforms, was proposed. The result was approved by an overwhelming majority of $80 \%$ of the electorate. Furthermore, the new constitution project which proposed a more egalitarian system, was accepted the following year by $65 \%$ of the electorate (Becker 2011:49-51).

Following the constitutional prescriptions based on the Sumac Kawsay, an ancient indigenous belief that proposes an austere, socialist and 'good' way of living, the Ecuadorian administration repatriated and mobilized the international monetary reserves which were previously deposited in foreign banks, towards public financial entities and national banks. The use of national savings has been condemned as fiscally irresponsible, but the new constitution established that fiscal policy cannot be divergent from generating incentives for productive investment. Between 2007 and 2011, public investment as a percentage of GDP grew at an average rate of $11.7 \%$. Correspondingly, social investment reached $26 \%$ of public spending in 2011 (Banco Central del Ecuador 2014). It has, therefore, been possible for the administration to provide absolute coverage for enrolment in primary, middle schools and high schools and to eliminate costs for medical consultation. In addition, the left-winged agenda proposed a network of social inclusion, the continuation of subsidies in basic services, and as well a series of programs to enhance the reduction of poverty and wage inequality (Ramírez Gallegos 2011:11-12).

Ecuador was not receiving the maximum utility from such industry; a situation attributable to the fact that $53.7 \%$ of oil production of that time belonged to private companies. Furthermore, as was mentioned before, the type of contract that the state maintained with the corporations was not profitable at all due to the major income was coming from renting the land rather than from production. This is the reason why, in 2010, the project of nationalization and renegotiation of contracts started, following the constitutional guidelines which dictate that strategic resources belong to Ecuadorians.

By 2012, the private production of oil was reduced to $25.6 \%$, the activities of companies like Texaco-Chevron and OXY were passed to the national oil company of Ecuador, Petro Ecuador. This re-nationalization of strategic resources allowed the Ecuadorian state to maximize benefits from the commodity boom of the last decade (Berriosa Marakb \& Morgensternc 2011:675-681). These series of reforms and the repossession of strategic resources has provided Correa's administration with a considerable increase in public revenues. As a matter of fact, Ecuadorian exportation revenue soared from US\$ 14,556.2 million in 2007 to US\$26,067.1 
million in 2014 of which the oil revenue share represents $47 \%$ of total exportations and $66 \%$ of the raw materials exportations. Hence the nationalization scheme has been a crucial factor for the maintenance of the social policies that Correa's administration has implemented.

On the other hand, the new constitution of Ecuador prohibited any type of outsourcing and hourly-paid activities. Forcing private companies to provide full-time contracts with fully remunerated salaries as well as social healthcare and a $15 \%$ share of profits to workers. By 2006, 800,000 workers were part of outsourcing companies. This represented $17 \%$ of the labour force. Thus, thousands of workers were introduced into the formal sector, which grew from 38\% from 2009 to $45 \%$ in 2010 (Banco Central del Ecuador 2014).

The working class, as was expected, demonstrated satisfaction with these measures. However, the private sector experienced considerable downsizing. It was alleged that it was unmanageable to maintain the same number of workers with this new package of benefits. This was reflected in the unemployment figures that grew from $7.9 \%$ in 2009 to $9.1 \%$ in 2010 (Banco Central del Ecuador 2014), (Uquillas 2007:37). To fight against the rise of unemployment, the government generated jobs by creating new state enti- ties. Since 2007, six national ministries in addition to a considerable number of regional secretaries and regulatory entities, were created.

This generated 110,000 new jobs between 2008 and 2014. Furthermore, in the last seven years, the minimum wage has grown $100 \%$, from US\$ 170 in 2007 to US\$ 340 in 2014. In the following graphs, it is possible to notice that not only has the unemployment rate fallen, employment in formal sectors has grown too. This could show that more workers are nowadays able to receive better work conditions, fully-paid salaries and social benefits. However, most employment generated in Ecuador has been the product of the creation of public sector entities. In 2013, 20.68\% of all formal employment were bureaucrats who do not necessary generate revenue for the state. In fact, it represents an enormous fiscal cost for the state to maintain such jobs.

\section{The key role of China on the Ecuadorian Buen Vivir}

The Buen Vivir could be perceived as a socialist model, which pursues to improve the standards of living of the Ecuadorians by reducing poverty and redistributing the wealth by creating pro-environmental and sustainable policies (SENPLADES 2009). The results of the Buen Vivir model, until 2014,

Figure 5: Figures the employment rates per sector in Ecuador (2008-2014)

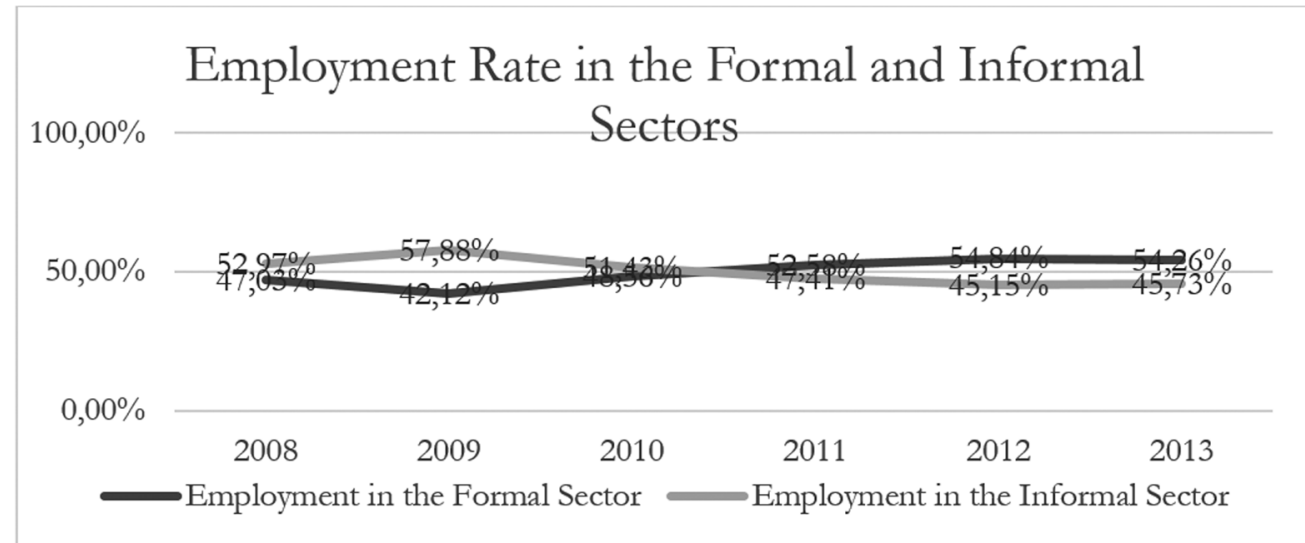

Source: Data retrieved from INEC (2014) 
had been remarkable.

Based on socioeconomic macro indicators, Ecuador not only expanded its economy by maintaining a consistent GDP annual growth, which grew from $3.5 \%$ to $7.9 \%$, but has also lifted $10 \%$ of its total population from poverty and, as was mentioned before, reduced its unemployment rates.

Furthermore, the socialist policies have improved the rate of secondary school enrolment up to $87 \%$ in 2013 from $46 \%$ in 2007 and reduced infant mortality rate. Ecuador also has seen an expansion of its industrial sectors and in general terms, living conditions of the Ecuadorians have been improved (Cepal 2015). This brief overview demonstrates how socialist policies have indeed demonstrated real development in the Ecuadorian state. Nevertheless, the efficacy of such endogenous plan development, as it has been described in the Ecuadorian national policy plan, has gone along with a series of exogenous factors, including the general expansion in the global commodity markets and alternatives for financial assistance that China has provided to the Ecuadorian government.

Until 2013, Ecuador had signed 4 agreements with the Chinese government. The contracts prescribed and anticipated the sale of a fixed number of oil barrels, so that the Ecuadorian government could receive financial assistance from the China Development Bank at floating interest of around 7\%. Consequently, the Ecuadorian foreign debt rose from US\$ 7392 million in 2009 to US\$ 16913 million in 2014, from which $37.6 \%$ is owed to China, (Banco Central del Ecuador 2014). Furthermore, at the beginning of
2015, the Ecuadorian economy was shrinking because of the fall of oil prices. This situation encouraged Rafael Correa to visit China to negotiate further lines of credit with Chinese officials.

After Correa attended the ministerial meeting of the Forum of China and the Community of Latin American and Caribbean States (CELAC), Correa reunited on various occasions with his counterpart Xi Jinping, resulting in the signing of a series of contracts which included new lines of Chinese credits that reached US\$ 7500 million, from which $26.6 \%$ has been designated merely to compensate fiscal imbalances produced by the downfall of the oil prices, while the rest will be used to finance the construction of what will be the biggest refinery in Ecuador.

Villavicencio (2013), who has analysed the nature of Chinese oil contracts, exposed the downsides of the Chinese cooperation scheme. He demonstrated that although the original aim of the Asian power was to secure energy supplies to meet burgeoning demand, nowadays, Chinese companies can freely trade a significant amount of Ecuador's crude oil exports. In 2013 only $46.5 \%$ of Chinese-controlled Ecuadorian oil exports went to China, with the balance resold to other countries, primarily the United States.

He concluded in 2013 that Ecuador will be a victim of a debt trap again compromising the sovereignty policies of the country. By 2015, such predictions seemed to have been making sense. With the continuing decline of oil prices, Ecuadorian officials have found themselves in a tricky position. If they want to perpetuate the 'Good Living' model, they

Figure 7: Figure of the contracts of the anticipated oil sales from Ecuador to China

\begin{tabular}{|l|l|l|}
\hline Contract & Loan Received & Future oil production anticipated sold \\
\hline $\mathbf{1}^{\text {st }}$ contract $(\mathbf{2 0 0 9})$ & 1000 USD millions & 2.88 million of barrels \\
\hline $\mathbf{2}^{\text {nd }}$ contract $(\mathbf{2 0 1 0})$ & 1000 USD millions & 1.08 million of barrels \\
\hline $\mathbf{3}^{\text {rd }}$ contract (2011) & 1000 USD millions & 2.88 million of barrels \\
\hline $\mathbf{4}^{\text {th }}$ contract $(\mathbf{2 0 1 1})$ & 2000 USD millions & 1.8 million of barrels \\
\hline
\end{tabular}

Source: Data retrieved from INEC, (2014)

$\underset{\text { 回回 }}{34}>$ 回


have to increase the taxation base, apply austerity measures or acquire more debt. All alternatives are expected to generate critical outcomes.

The rise in taxes and the measures taken during 2015 have generated a series of protests and rioting in the main cities of Ecuador. Such a situation not only has destabilized the political order, but also slowed productivity. Furthermore, the low prices of oil, which translates in a reduction of revenue for the state, will affect its ability to make repayment of debts, generating a situation in which a share of the future loans that Ecuador acquire will have to be used for the repayment of interest and fiscal imbalances, as has happened in the first period of 2015.

Hence the contraction of the prices of commodities in the global markets has exposed the pitfalls of socialist models in Latin America, which have evidently demonstrated to be maintainable only due to a market boom, rather than to real expansion within the productivity sectors. Furthermore, reckless social expenditure has been upheld by carelessly expanding foreign debt and compromising the allocation of strategic resources for various years, currently around $80 \%$ of Ecuador's exported oil is handled by Chinese firms, limiting the state ability to secure the best market price for its crude (Villavicencio 2013 ).

The Yasuni case is a clear demonstration of Chinese power. It demonstrates that they have great influence on Ecuadorian policy-making, especially in energy and commercial matters. China has leveraged its influential power not only by generating large sums of debt, but also by controlling the future oil production of Ecuador. Chinese oil companies have displaced Western companies from Ecuadorian territory and have gained enough resources to influence governmental decisions in favour of their interests. On the other hand, Ecuadorian officials have entered a situation of dependency in which the sovereignty of its policies is reliant upon ensuring the interests of a hegemonic power are fulfilled.

The Ecuadorian constitution prohibits any type of extraction of natural resources in protected areas. However, from 2016 over 846 million barrels of oil will be drilled from the ITT block (Ishpingo, Tambococha and Tiputini), located in the Yasuní National Park. The Yasuni, which is in the Ecuadorian Amazon region, was designated by the UNESCO as biosphere reserve in 1989 and is claimed to hold more than 100000 of different species of flora and fauna, besides being the home of two uncontacted indigenous tribes.

The Yasuni contains around $20 \%$ of Ecuador's fossil fuel reserves, which is the reason why many energy companies have been operating in the peripheral areas of the national park since the 1970s. However, the core areas, including the ITT blocks, have never been touched. Nonetheless, due to external pressures and fiscal deficits, this situation has changed. In 2014, the Ecuadorian National Assembly, declared the area as a "national interest", taking away its condition as a protected area and therefore allowing extraction of natural resources in such areas.

On February of 2015, it was revealed that the Ecuadorian government had for some years been negotiating a further 1-billion-dollar loan with China, giving Chinese oil companies the right to explore and exploit the Yasuni-ITT oil reserves. Nowadays, Block 14, part of the ITT, is operated by Petro Oriental, which is owned by the China National Petroleum Corporation (CNPC) and which owns $55 \%$, and Sinopec, which owns the other 45\% (Ortiz 2015).

\section{CONCLUSIONS}

This paper has outlined the way in which China has established a demarcated global scheme of cooperation that has proven to be attractive to many non-western states. During the last decades, the development of China has been remarkable and its influence over developing regions has shown that it is not merely a commercial and economic power. The massive accumulation of foreign exchange reserves, the vast quantity of finan- 
cial assistance provided, the increasing share of participation in natural resource markets as well as an extensive agenda of bilateral cooperation are factors that demonstrate the capabilities of China's vast global influence. The Chinese economic expansion has brought to developing economies a series of opportunities and pitfalls. China's appetite for commodities has opened a great door for commercial sectors of the developing economies around the globe. Furthermore, the lending programs of the Chinese Development Bank have demonstrated to be a remarkable alternative for the IMF or the World Bank, without regarding the political model or the ideological line of thought, China has become since 2001, a sine qua non-for the contemporary construction of commercial and foreign policies of the developing and developed states around the globe.

For Latin American states, which have not been capable to accomplishing a real development under the regulations of a Western economic agenda for 30 years, the Chinese cooperation scheme, which includes financial assistance and commercialization of strategic resources has provided them with the opportunity to generate more autonomous and socialist policies, which have demonstrated better outcomes than under the neoliberal guidelines. However, as was demonstrated in Chapters 2 and 3, the sustainability and success of these models are clearly reliant on Chinese loans and high prices in commodity markets.

By 2015, the pitfalls of the Chinese cooperation system and problems with the Latin American socialist models have become evident. The expansion of the economy in Latin American states has been a direct result of a boom in the commodity market. Such extraordinary incomes have allowed the states to recklessly expand their fiscal expenditure and to artificially develop their economies and generate several social policies that have produced political stability. However, since 2014, the global price of commodities has fallen causing profound deficits in the balance of payments of the states which maintain such socialist models. Therefore, they have acquired large sums of debt, especially with China, to compensate such imbalances. This situation has demonstrated the unsustainability of such models and the large dependency that they had on endogenous factors. 


\section{BIBLIOGRAPHIC REFERENCES}

Banco Central del Ecuador. (2003). Información Económica. Quito: Banco Central del Ecuador. Retrieved from http://www.bce.fin. ec/index.php/informacion-estadistica-1

Banco Central del Ecuador. (2014). Estadisticas Macroeconómicas. Quito: Banco Central del Ecuador.

Becker, M. (2011). Correa, Indigenous Movements, and the Writing of a New Constitution in Ecuador. Latin American Perspectives, 2 (1) 47-62.

Berriosa, R., Marakb, A., \& Morgensternc, S. (2011). Explaining hydrocarbon nationalization in Latin America: Economics and political ideology. Review of International Political Economy, 18 (5), 673-697.

Cavallo, Domingo. (2004). Argentina and the IMF During the Two Bush Administrations. International Finance, 7(1), 137-150.

Cepal. (2015). Cepal Stats. Retrieved from http://interwp.cepal.org/cepalstat/WEB_cepalstat/Portada.asp?idioma $=\mathrm{e}$

Correa, R. (October 13, 2014). Rafael Correa: el socialismo del siglo xxi, son principios no modelos. Reto Perú. (J. Lanata, Entrevistador). Retrieved from https://www. youtube.com/watch?v=hYHV6eagENk

Dieterich, H. (2003). Three Criteria in the Definition of a Socialist Economy. Revista Internacional de Filosofia Iberoamericana y Teoría Social, 8 (20), 117-132.

Do Alto, H. (2008). La revolución de Evo Morales o los caminos sinuosos de la refundación de Boliva. En F. Gaudichaud (Ed.), El volcán Latinoamericano Izquierdas, movimientos sociales y neoliberalismo (pp. 164-183). Paris: Textuel.
Ellsworth, B. 2. (20 de abril de 2015). Venezuela recibe 5.000 Millones por nuevo préstamo de China. Reuters.

Francoise, L. (2013). From foreign trade to international investment: a new step in China's integration with the world economy. Springer Econ Change Restruct, 46 (1), 2543.

Hurrell, A. (2006). Hegemony, liberalism and global order: what space for would-be great powers? International Affairs, 82 (1), $1-19$.

INE (2007). Instituto Nacional de Estadistica, Bolivia. Retrieved from http://www.ine. gob.bo/

Instituto Nacional de Estadística y Censo. (2014). Indicadores laborales. Quito: INEC.

Jaramillo-Jassir, M. (2012). Populism and democratic consolidation during Rafael Correa's administration. Is it possible to ensure democracy through populism? Reflexión Política, 142-153.

León-Manriquez, J., \& Hearn, A. (2011). China Engages Latin America: Tracing the Trajectory. (1 ed.). London: Lynne Rienner Publishers.

Manriquez, J., \& Álvarez, L. (2014). 'Mao's steps in Monroe's backyard: towards a United States-China hegemonic struggle in Latin America? Revista Brasileira de Política Internacional, 9 (27), 9-27.

Navarro, R. (2015). La exitosa política económica de Kirchner. El Chileno.

Nazmi, N. (2001). Failed Reforms and Economic Collapse in Ecuador. The Quartery Review of Economic and Finnance, 41 (1) 727-735.

Oliva, C. (2010). Argentina's Relations with China Opportunities and Challenges. En A. H. Fernández (Ed.), Latin America Fa- 
cing China South-South Relations beyond the Washington Consensus (113-129). Ney York: Berghahn Books.

Opec. (2015). OPEC, Venezuela. Retrieved from http://www.opec.org/opec web/en/ about us/171.htm

Ortiz, F. (January 2015). China, Latin America and the environment. Retrieved from http://dialogochino.net/yasuni-silent-investment/

Oxford Analytica. (2014). ECUADOR: Yasuni deal shows oil under china's control. Oxford: Oxford Analytica Ltd.

Panizza, F. (2009). Contemporary Latin America Development and Democracy beyond the Washington Consensus. New York: Zed Books.

Philips, N. (2011). Re-ordering the Region? China, Latin America and the Western Hemisphere (Review). European Review of Latin American Studies, 90 (1), 89-99.

Poveda, P. (2010) Latin America Facing China South-South Relations beyond the Washington Consensus. Ney York: Berghahn Books.

Quincy, S. (2011). If Not Now, When? Reflections on Socialism in the 21st Century. Capitalism Nature Socialism, 22 (3), 57-72.

Ramirez Gallegos, F. (2011). Political Change, State Autonomy, and Post-Neoliberalism in Ecuador. Latin American Perspectives, 20 (1), 1-15.

Rangel, R. \& Soto Reyes, E. (2012). El Consenso de Washington: la instauración de las políticas neoliberales. América Latina. Política y Cultura, 37 (1), 35-64.

Rhys, J. (2010). China's Global Expansion and Latin America. Latin American Studies, Cambridge University Press, 42 (1), 809-
837.

Richard, F. (1990). What Washington means by policy reforms (comment). In J. Williamson (Ed.), Latin American Adjustment How much has happened? (21-24). Washington: Institute for International Economics.

Rowan, M. (2003). Bolivia y el "Consenso de Washington" se desentienden. Economía Hemeroteca, 8 (20).

Rudd, K. (2015). Are China and the US doomed to conflict? Colorado: TED talks.

SENPLADES. (2009). Plan Nacional para el Buen Vivir 2009-2013. Quito: SENPLADES.

Silva, S. (2015). The boom and crisis of the Convertibility Plan in Argentina. Brazilian Journal of Political Economy, 3 (35), 325342.

Svampa, M. (2008). Argentina, del que se vayan todos a la exacerbación de lo nacional-popular. En F. Gaudichaud (Ed.), El volcán Latinoamericano Izquierdas, movimientos sociales y neoliberalismo (231-250). Paris: Textuel.

Torres, D. (2015). Venezuela tiene el doble de ministerios que otros países. El Universal.

Toussaint, E. (2003). La crisis de la deuda en América Latina en los siglos XIX y XX. Seminario Internacional "América Latina y el Caribe: salir del impase de la deuda y del ajuste". Brusels.

Uquillas, C. (2007). El outsourcing en el Ecuador. Observatorio de la Economía Latinoamericana.

Urdinez, F. (2014). The Political Economy of the Chinese Market Economy Status given by Argentina and Brazil. Ciencias Sociais-Universidade de São Paulo. 


\section{Unach}

Villavicencio, F. (2013). Ecuador Made in China (1st ed.). Quito: American Institute for democracy.

Williamson, J. (1990). Latin American Adjustment. Washington: Institute for International Economics.

World Bank. (2014). Global Economic Monitor (GEM) Commodities. Retrieved from http://databank.worldbank.org/data/reports.aspx? source = global-economic-monitor-(gem)-commodities\#

Wu, F. \& De Wei, K. (2014). From Financial Assets to Financial Statecraft: the case of China and emerging economies of Africa and Latin America. Journal of Contemporary China, 89 (23), 781-803.

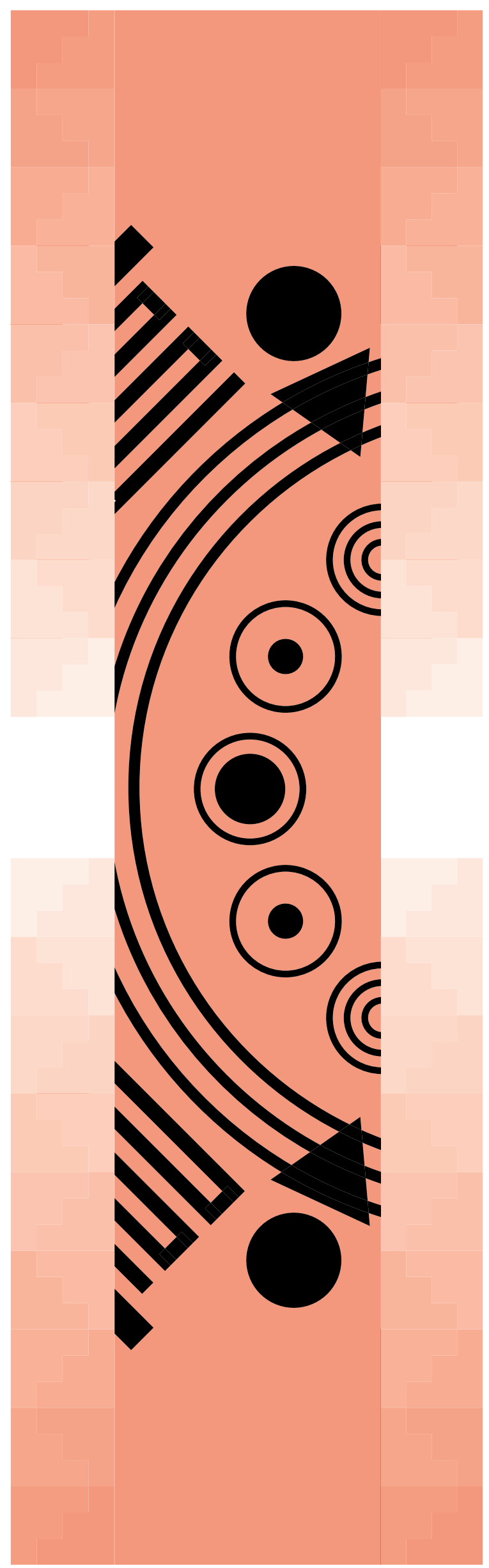

